\title{
Considerable Variation of Antibacterial Activity of Cu Nanoparticles Suspensions Depending on the Storage Time, Dispersive Medium, and Particle Sizes
}

\author{
Olga V. Zakharova, ${ }^{1}$ Anna Yu. Godymchuk, ${ }^{2,3}$ Alexander A. Gusev, ${ }^{1,2}$ \\ Svyatoslav I. Gulchenko, ${ }^{2}$ Inna A. Vasyukova, ${ }^{1}$ and Denis V. Kuznetsov ${ }^{2}$ \\ ${ }^{1}$ Tambov State University named after G.R. Derzhavin, 33 Internatsionalnaya street, Tambov 392000, Russia \\ ${ }^{2}$ National University of Science and Technology "MISIS", 4 Leninsky pr., Moscow 119991, Russia \\ ${ }^{3}$ National Research Tomsk Polytechnic University, 30 Lenina Avenue, Tomsk 634050, Russia \\ Correspondence should be addressed to Alexander A. Gusev; nanosecurity@mail.ru
}

Received 28 November 2014; Revised 29 April 2015; Accepted 14 May 2015

Academic Editor: Petros Gikas

Copyright ( $) 2015$ Olga V. Zakharova et al. This is an open access article distributed under the Creative Commons Attribution License, which permits unrestricted use, distribution, and reproduction in any medium, provided the original work is properly cited.

\begin{abstract}
Suspensions of $\mathrm{Cu}$ nanoparticles are promising for creating the new class of alternative antimicrobial products. In this study we examined copper nanoparticles of various sizes obtained by the method of wire electric explosion: nanopowder average size $50 \mathrm{~nm}(\mathrm{Cu} \mathrm{50)}$ and $100 \mathrm{~nm}(\mathrm{Cu} 100)$. The paper presents the complex study of the influence of physicochemical properties such as particle size and concentration of the freshly prepared and 24-hour suspensions of $\mathrm{Cu}$ nanoparticles in distilled water and physiological solution upon their toxicity to bacteria E. coli M-17. Ionic solution of $\mathrm{Cu}^{2+}$ and sodium dichloroisocyanurate was used for comparison study. It has been shown that decrease in the nanoparticle size leads to changes in the correlation between toxicity and concentration as toxicity peaks are observed at low concentrations $(0.0001 \cdots 0.01 \mathrm{mg} / \mathrm{L})$. It has been observed that antibacterial properties of $\mathrm{Cu} 50$ nanoparticle suspensions are ceased after 24-hour storage, while for $\mathrm{Cu} 100$ suspensions no correlation between antibacterial properties and storage time has been noted. $\mathrm{Cu} 100$ nanoparticle suspensions at $10 \mathrm{mg} / \mathrm{L}$ concentration display higher toxicity at substituting physiological solution for water than $\mathrm{Cu} 50$ suspensions. Dependence of the toxicity on the mean particle aggregates size in suspension was not revealed.
\end{abstract}

\section{Introduction}

Nanotechnologies are expected to be developed at medicine, microelectronics, optics, catalysis, sensor analysis, and other manufacturing sectors [1-4]. Nowadays, creation of a new class of alternative antimicrobial agents may be one of the promising applications for metal nanoparticles [5-7] because of the increasing of antibiotic resistance in microorganisms $[8,9]$ presenting grave hazard for public healthcare [10].

At the present time a considerable number of papers studying antibacterial properties of metal nanoparticles [11, 12] pose a wide spectrum of antibacterial activity without resistance development in microbes [13-19]. Meanwhile, due to high biological activity, comparatively low cost, and ecological safety, copper nanoparticles can be considered as promising multifunctional antibacterial agents [20].

Several authors showed that nanosized cuprum particles display antimicrobial activity towards wide range of microorganisms, including pathogenic bacteria [21, 22]. It is important to note that antibacterial properties are displayed by cuprum nanoparticles [23-25], cuprum compounds [2630], and complex nanomaterials containing cuprum [31-34].

Cytotoxicity of $\mathrm{Cu}$ nanoparticles results not only from the small size of the particles, high specific surface value, and close interaction with microbial membranes but also from formation of leached cuprum-peptide complexes leading to several-fold increase in reactive oxygen intermediate (ROI) generation, cell viability decrease, and general biomass 
growth suppression [35]. Storage of cuprum nanoparticle suspensions for some time may lead to $\mathrm{Cu}^{2+}$ ions release into the culture medium, as cuprum has high reaction activity [36].

It was also found that cuprum nanoparticles display on the one hand low toxicity towards humans and on the other hand show high antimicrobial effect towards the cells of testcultures of gram-positive and gram-negative bacteria which makes them applicable for creating the new wound healing products [22]. By the example of E. coli it was shown that utilization of $\mathrm{Cu}$ nanoparticles is of high potential for creating new bactericidal dressings as human tissues are resistant to cuprum [37], while microorganisms are highly sensitive to it [38-40].

However, creation of such products is hampered by the lack of experimental data on the biological activity alteration when passing the upper nanoscale limit $(100 \mathrm{~nm})$ and at transferring from ion-molecule form to nanoscale through the lower limit $(10 \mathrm{~nm})$.

Studies of nanoparticle antimicrobial properties have made it possible to discover possible mechanisms of their toxic action including oxidative stress due to reactive oxygen intermediates generation, lipid peroxidation, protein oxidation and DNA degradation in cells, mechanical damage of cell membranes [41], and influence of some physicochemical characteristics such as size, shape, and production method upon the level of biocidal impact [5, 23, 42-45].

At the same time such factors as agglomeration and rapid oxidation have made this research area difficult. Although, some researches use stabilizers in order to eliminate these factors [46-48], joint use of nanoparticles and stabilizers may lead to synergistic effects. Besides, nanoparticle antibacterial properties are usually studied in vitro in water or agarous media but not in biological fluids. Moreover, dependence of nanoparticle suspensions toxicity upon their storage time is still unstudied. Thus, mechanisms which are connected with nanoparticles behavior in colloidal systems and essential for cytotoxicity are still undiscovered.

This paper shows alteration of copper nanoparticles bactericidal properties depending on physicochemical characteristics of the particles, dispersive medium, and suspension storage time.

\section{Materials and Methods}

2.1. Nanoparticles. In this study we examined copper nanoparticles of various sizes obtained by the method of wire electric explosion in Ar-medium with additive of $\mathrm{H}_{2}(10 \mathrm{vol}$. $\%)$ at the pressure of $1.52 \cdot 10^{5} \mathrm{~Pa}$, capacitive storage charging voltage $-24 \mathrm{kV}$ (the wire diameter $0.3 \mathrm{~mm}$, length $75 \mathrm{~mm}$ ). To maintain metal stability to oxidation nanopowders were passivated by slow air oxidation (Advanced Powder Technologies LLC, Tomsk, Russian Federation [49]). According to the manufacturer arithmetic average size of the particles was $50 \mathrm{~nm}\left(\mathrm{Cu} 50\right.$, specific surface area $\left.12 \mathrm{~m}^{2} / \mathrm{g}\right)$ and $100 \mathrm{~nm}\left(\mathrm{Cu} \mathrm{100,} \mathrm{specific} \mathrm{surface} \mathrm{area} 6.8 \mathrm{~m}^{2} / \mathrm{g}\right)$; the nanoparticles were spherical in shape (Figures 1 and 2).
TABLE 1: Values of oxidation film thickness for cuprum nanoparticles.

\begin{tabular}{lcc}
\hline Sample & Oxygen content, \% & Oxidation film thickness, $\mathrm{nm}$ \\
\hline $\mathrm{Cu} 50$ & 5.1 & 0.6 \\
$\mathrm{Cu} 100$ & 6.3 & 1.5 \\
\hline
\end{tabular}

On the assumption that the shape of the particles is almost spherical, thickness of the oxidation film $(X)$ on the particle surface was calculated using the following formulas:

$$
\begin{aligned}
X & =R_{\mathrm{part}}-R_{\mathrm{Me}}, \\
V_{\mathrm{part}} & =\frac{4}{3} \cdot \pi \cdot R_{\mathrm{part}}{ }^{3}, \\
V_{\mathrm{Me}} & =V_{\mathrm{part}} v_{\mathrm{Cu}}, \\
R_{\mathrm{Me}} & =\left(\frac{3}{4} \cdot \frac{V_{\mathrm{Me}}}{\pi}\right)^{1 / 3},
\end{aligned}
$$

where $R_{\text {part }}$ is the particle radius, $V_{\text {part }}$ is the particle volume, $V_{\mathrm{Me}}$ is the volume of the metallic sphere, $R_{\mathrm{Me}}$ is the radius of the metallic part, and $R_{\text {part }}$ is the radius of the particle coated with oxidation film.

The calculation results for oxidation film for the initial samples are presented in Table 1.

The powders were stored in sealed glass vials at the temperature of $20 \pm 1^{\circ} \mathrm{C}$; the vials were opened not earlier than a week before the suspension preparation.

2.2. Nanoparticles Suspensions. The nanoparticle suspensions were prepared with doubly distilled water $(\mathrm{pH}=7.1 \pm$ 0.2 ) and $9 \% \mathrm{NaCl}$ solution ( $\mathrm{pH} 7.1 \pm 0.2$ ). Precisely weighed quantities were determined using ViBRA HT analytical balance (Shinko Denshi, Japan, with precision $\pm 0.0001 \mathrm{~g}$ ), poured into extemporaneously prepared dispersion vehicle and stirred with a glass rod for 20 seconds. After stirring the suspensions were processed in Ultrasonic Cleaner CD-4800 (Codyson, China) for 40 seconds ( $70 \mathrm{~W}, 44 \mathrm{~Hz}$, volume $1.4 \mathrm{~L}$ ). Initial copper concentration in the solutions was $10 \mathrm{mg} / \mathrm{L}$; the initial solutions were then diluted with doubly distilled water or physiological solution to prepare suspensions with copper concentrations of $1,0.1,0.01,0.001$, and $0.0001 \mathrm{mg} / \mathrm{L}$.

The laboratory glassware for sample storage and biotesting was washed with mixture of potassium bichromate and sulphuric acid (chromic-sulphuric acid mixture). The glassware inner surfaces were gently wetted with chromicsulphuric acid mixture and left for 2-3 hours; the glassware was then washed thoroughly with tap water, disacidified with sodium bicarbonate solution, and washed for 3-4 times with doubly distilled water.

Toxic properties were analyzed in freshly prepared (stored for no more than 1 hour) and stored for no more than 24-hour suspensions.

\subsection{Comparison Solutions}

2.3.1. $\mathrm{Cu}^{2+}$ Ion Solutions. Solutions containing $\mathrm{Cu}^{2+}$ ions were used for comparison. Solutions were prepared by 

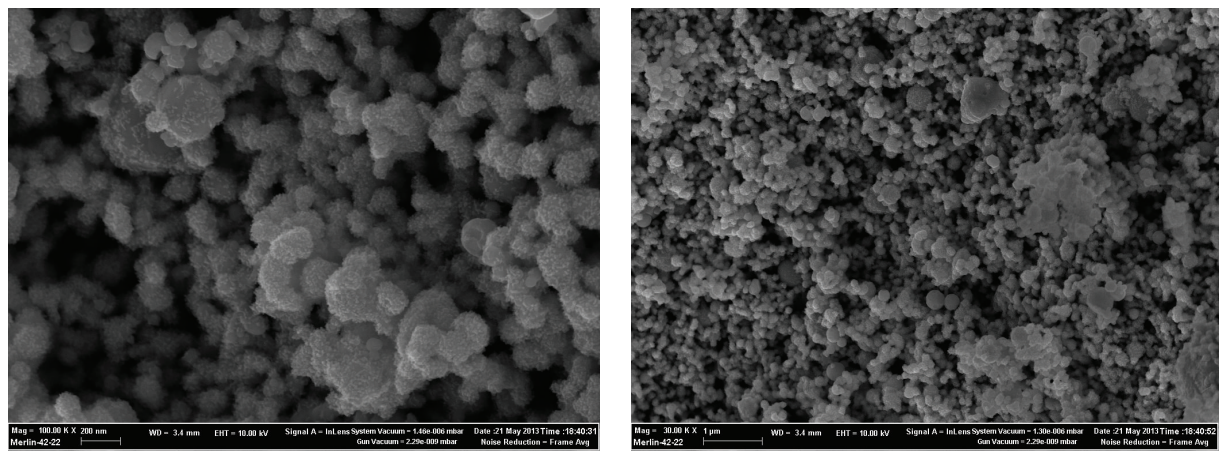

FIGURE 1: Electron micrograph of $\mathrm{Cu} 50$ nanoparticles powders.
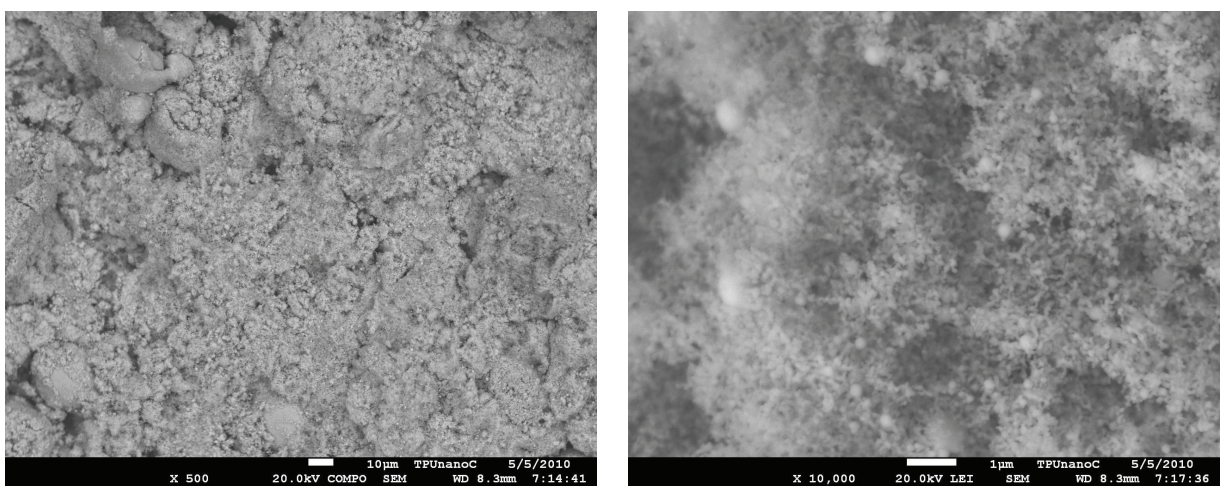

FIGURE 2: Electron micrograph of $\mathrm{Cu} 100$ nanoparticles powders.

dissolving copper chloride $\left(\mathrm{CuCl}_{2} * 2 \mathrm{H}_{2} \mathrm{O}\right.$, GOST 4167-74, Russian Federation) in doubly distilled water $(\mathrm{pH}=7.1 \pm$ 0.2 ) with conductivity of $0.2 \mu \mathrm{S}$ and in physiological solution $(\mathrm{pH} 7.1 \pm 0.2)$.

2.3.2. Sodium Dichloroisocyanurate Solutions. Aqueous solutions of sodium dichloroisocyanurate $\left(\mathrm{C}_{3} \mathrm{Cl}_{2} \mathrm{~N}_{3} \mathrm{NaO}_{3}, \mathrm{SDC}\right)$ (NPF Praktika LLC, Russian Federation) were employed for positive control; they were also prepared with doubly distilled water and physiological solution. Sodium dichloroisocyanurate is widely used as a disinfectant efficient against gram-positive and gram-negative bacteria, viruses, Candida fungus, and dermatophytes [50].

Solutions of $\mathrm{Cu}^{2+}$ ions and sodium dichloroisocyanurate were prepared within concentration range of $0.0001 \cdots$ $10 \mathrm{mg} / \mathrm{L}$.

2.4. Toxicity Evaluation. Copper nanoparticle solutions toxicity was measured by bioluminescence technique used for microbiological and molecular genetic evaluation of nanomaterials influence on microbiocenosis species [51-54]. The method measures modifications in bioluminescence intensity of the genetically modified photobacteria strain E. coli M-17 influenced by nanoparticles present in the analyzed sample as compared with the control sample. Alteration in the bioluminescence intensity of the tested object in the analyzed sample as compared with the control sample containing no toxic agents was taken as effect criterion. Bioluminescence intensity reduces in proportion to toxic effect.

Toxic effect of the studied nanomaterial sample upon bacteria is determined by their bioluminescence inhibition after 30-minute exposure period. The quantitative test-reaction parameter assessment is expressed as a toxicity index $T$ which is a nondimensional quantity determined from the formula $T=100\left(I_{o}-I\right) / I_{o}$, where $I_{o}$ and $I$ are luminous intensities of the control and tested samples accordingly, while the exposition time of the examined sample with the test-object is fixed.

The technique allows for three threshold levels of the toxicity index:

(1) acceptable degree when toxicity index $T$ is in the range from 0 to 20 ;

(2) medium degree when toxicity index $T$ is in the range from 20 to 50 ;

(3) high degree when toxicity index $T$ equals or is higher than 50 .

Negative toxicity index values are regarded as nontoxicity.

In the process of toxicity index evaluation parallel measurements of control and studied samples were carried out. For higher data reliability the number of repeat sample tests was increased up to 5 measurements.

The measurements were carried out using Biotox-10 specialized luminometer (Russian Federation). The first test 
TABLE 2: $\mathrm{pH}$ value of $\mathrm{Cu} 50$ nanoparticle suspensions.

\begin{tabular}{lcccc}
\hline Concentration $(\mathrm{mg} / \mathrm{L})$ & $\mathrm{Cu} 50+\mathrm{H}_{2} \mathrm{O}(0.5 \mathrm{~h})$ & $\mathrm{Cu} 50+\mathrm{H}_{2} \mathrm{O}(24 \mathrm{~h})$ & $\mathrm{Cu} 50+\mathrm{PS}(0.5 \mathrm{~h})$ & $\mathrm{Cu} 50+\mathrm{PS}(24 \mathrm{~h})$ \\
\hline 0.0001 & 7.6 & 7.0 & 7.2 & 7.2 \\
0.001 & 7.6 & 7.1 & 7.1 & 7.1 \\
0.01 & 7.3 & 7.1 & 7.1 & 7.2 \\
0.1 & 7.3 & 7.2 & 7.2 & 7.2 \\
1 & 7.3 & 7.2 & 7.3 & 7.2 \\
10 & 7.4 & 7.2 & & \\
\hline
\end{tabular}

phase was carried out straight after the solutions were prepared; the second phase was carried out in 24 hours. The solutions $\mathrm{pH}$ value was checked before each measurement using digital pH-meter pH-2005 SELECTA (Barcelona, Spain).

2.5. Measurement of the Dispersity. The particle/aggregate size distribution in the prepared suspensions was evaluated at the temperature of $25^{\circ} \mathrm{C}$ using the dynamic light scattering technique and the Malvern Zetasizer Nano device, USA (a helium-neon laser with the power of $4 \mathrm{~mW}$ and the $633 \mathrm{~nm}$ wave length). For these measurements, a versatile capillary U-shaped polystyrene cuvette was used. The dry cuvette was delicately washed with distilled water; then $1 \mathrm{~mL}$ of the suspension under study was poured in, avoiding air bubbles formation. Each measurement was repeated thrice. Based on the obtained size distribution; the average particle size at each point was calculated according to the following formula:

$$
d_{\mathrm{av}}=\sum d \frac{q(\%)}{100(\%)}
$$

where $d$ represents the particle size in dispersion and $q$ is the differential percent of particles with size $d$ in the dispersion.

\section{Results and Discussion}

Molecules interact with macroscopic bodies' surfaces according to the laws of molecular statistics, while in transition to nanoobjects and live cells statistics of comparatively large objects and their contact interactions acquire importance, in which case the particle roles change qualitatively: the larger ones may be considered as motionless while nanoparticles and metallic ions may be considered as more mobile than bacterial cells, as their dimensions $(1-100 \mathrm{~nm})$ are smaller than average $E$. coli cell size $(1-3 \mu \mathrm{m}$ in length, $0.5-0.8 \mu \mathrm{m}$ in width). Owing to the fact that reactivity of the solids is in proportion to their surface area, other factors, including concentration being equal, the choice of copper configurations such as $50 \mathrm{~nm}$ and $100 \mathrm{~nm}$ copper suspensions and $\mathrm{Cu}^{2+}$ containing solutions, were justifiable for the study. Presumably high biological activity per unit mass was to be observed for all the chosen configurations as compared to larger particles.

3.1. Study of the Antibacterial Properties of Cu 50 Nanoparticle Suspensions. The study of the antibacterial properties of 0.5 hour aqueous $\mathrm{Cu} 50$ nanoparticle suspensions has allowed us to discover that toxicity observed at the lowest concentrations of $0.0001 \mathrm{mg} / \mathrm{L}$ decreases from 40 to 20 units with nanoparticle concentration growth up to $0.01 \mathrm{mg} / \mathrm{L}$, no toxicity is observed in suspensions with $0.1 \ldots 1 \mathrm{mg} / \mathrm{L}$ concentration, and the maximum value ( $\approx 50$ units) is recorded at $10 \mathrm{mg} / \mathrm{L}$ suspension (Figure 3(a)). The solutions $\mathrm{pH}$ value monitoring throughout the testing process indicated slight deviation of $\mathrm{pH}$ up to 7.6 from the normal values of 6.8-7.4 specifically in suspensions with 0.0001 and $0.001 \mathrm{mg} / \mathrm{L}$ concentrations (Table 2). The highest value of toxicity index in $10 \mathrm{mg} / \mathrm{L}$ suspension may be connected with increased concentration of $\mathrm{Cu}^{2+}$ ions dispersed in the solution as a result of the sample dissolution during its hour-long exposure $[35,55]$.

According to the experiment, 24-hour suspensions of $\mathrm{Cu} 50$ particles display no antibacterial effect (Figure 3(a)) in the studied concentration interval. Lack of toxicity may be explained by the storage period as copper particles with size $<150 \mathrm{~nm}$ may oxidize to $11-14 \mathrm{wt}$.\% developing on the surface oxide-hydroxide forms of copper blocking further dissolution [55].

Within the studied concentration range toxicity index for physiological solution (PS) medium displays the highest values in 0.5 -hour suspensions at particle concentrations of $0.01 \mathrm{mg} / \mathrm{L}$ (>50 units) and $10 \mathrm{mg} / \mathrm{L}(\approx 30$ units) (Figure 3(b)). 24-hour $\mathrm{Cu} 50$ nanoparticle suspensions in physiological solution display no toxic effect on the tested object. Thus, the highest toxic effect is observed in freshly prepared $\mathrm{Cu}$ 50 nanoparticle suspensions. Minimum inhibitory concentrations (MIC) and Minimum bactericidal concentrations (MBC) were evaluated by means of the computational method [56]. Neither MIC nor MBC could be calculated for $\mathrm{Cu} 50$ nanoparticles because of the nonlinear type of the dependence.

Dispersion analysis of 0.5 -hour aqueous $\mathrm{Cu} 50$ nanoparticle suspensions showed insignificant alteration in particle aggregates sizes $\left(d_{\mathrm{av}}\right)$; slight growth of $d_{\mathrm{av}}$ from 177 to 250$270 \mathrm{~nm}$ was observed with concentration increase. In 24 hours $d_{\mathrm{av}}$ of aggregates in suspensions decreases slightly; it may be connected with larger aggregates subsidence (Figure 4(a)). In physiological solution a tendency towards increase of $d_{\mathrm{av}}$ of the aggregates in 0.5-hour solutions from 108 to $226 \mathrm{~nm}$ was observed together with increase in concentration from 0.0001 to $10 \mathrm{mg} / \mathrm{L}$, respectively (Figure $4(\mathrm{~b})$ ). In 24 hours $d_{\mathrm{av}}$ value changes insignificantly.

Comparison of toxicological and dispersion analysis data leads to suggestion that size of aggregates insignificantly changing with storage time and concentration growth is not 


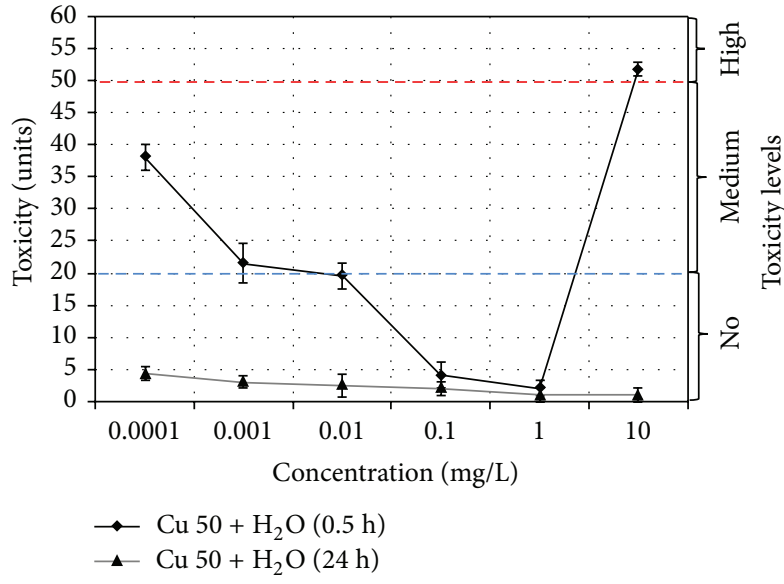

(a)

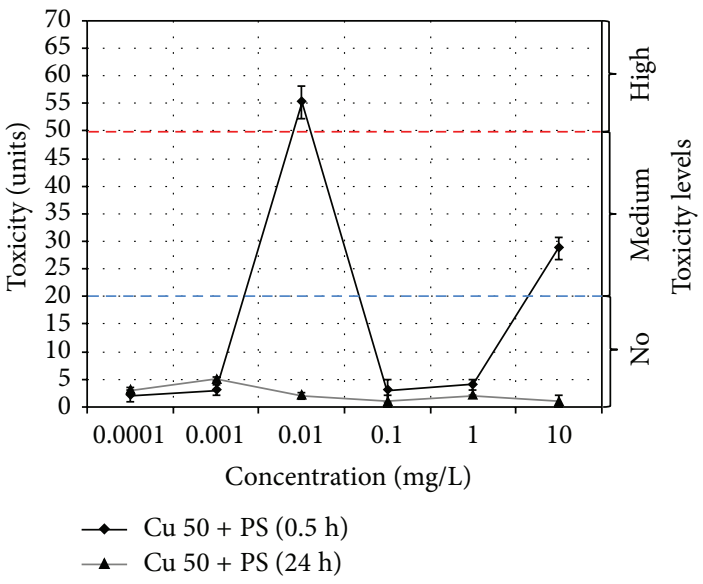

(b)

FIGURE 3: Changes in the toxicity index for $\mathrm{Cu} 50$ nanoparticle suspensions based on (a) water, $\mathrm{Cu} 50+\mathrm{H}_{2} \mathrm{O}$, and (b) physiological solution, $\mathrm{Cu} 50$ + PS.

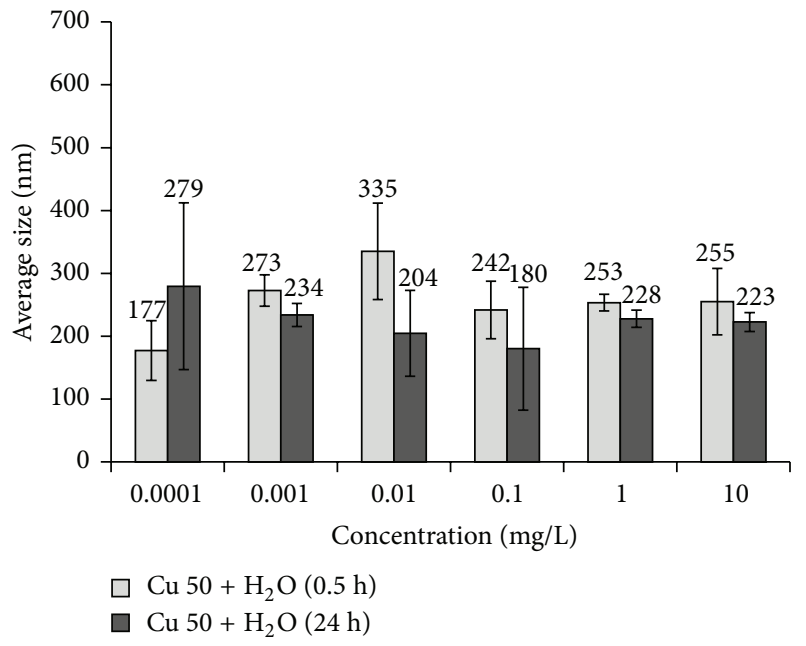

(a)

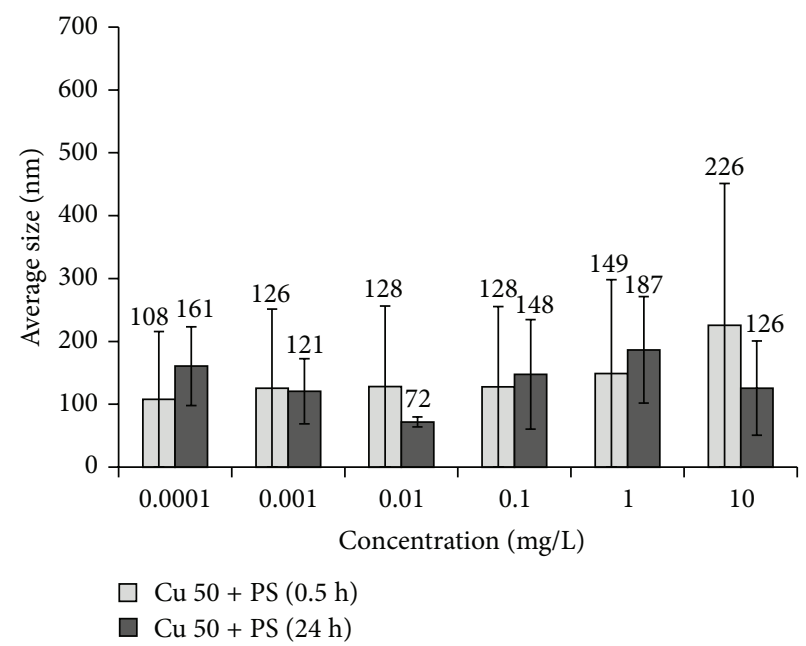

(b)

FIGURE 4: Changes in average size of $\mathrm{Cu} 50$ nanoparticle suspensions based on (a) water, $\mathrm{Cu} 50+\mathrm{H}_{2} \mathrm{O}$, and (b) physiological solution, $\mathrm{Cu}$ $50+$ PS.

the main reason for variations in antibacterial properties. It is probable that chemical state of the surface is much more important for toxicity level variations than dispersity.

\subsection{Study of the Antibacterial Properties of Cu 100 Nanopar-} ticle Suspensions. According to the data obtained from bioluminescence technique aqueous $\mathrm{Cu} 100$ nanoparticle suspensions show no toxic effect on bacteria in the studied range of concentrations (Figure 5(a)). The same properties are characteristic for PS suspensions, excluding $10 \mathrm{mg} / \mathrm{L}$ suspensions where medium toxicity level of 35-50 units is observed (Figure 5(b)).

Minimum inhibitory concentration (MIC) was assessed for physiological solution: it is $4 \mathrm{mg} / \mathrm{L}$ for the freshly prepared suspension and $5 \mathrm{mg} / \mathrm{L}$ for the 24-hour suspension. Minimum bactericidal concentration (MBC) was not detected in the studied range of concentrations.
Data obtained from $\mathrm{pH}$ measurements display that slight shift in $\mathrm{pH}$ value up to 7.7 is observed only in $10 \mathrm{mg} / \mathrm{L}$ PS suspensions of $\mathrm{Cu} 100$ nanoparticles (Table 3).

Comparative analysis of bactericidal properties of the particles in $\mathrm{H}_{2} \mathrm{O}$ and PS media shows increase of toxicity index in the presence of electrolyte. The received data corresponds with the previous experiments stating that presence of more polar solvent $\left(\mathrm{Cl}^{-}\right.$ions) increases the degree of $\mathrm{Cu}$ 100 particles dissolution [55]. Detachment of large amount of $\mathrm{Cu}^{2+}$ ions having higher diffusion activity than solid particles may lead to increase in cytotoxicity.

According to the data obtained from dynamic light scattering technique storage time and concentration have more effect on degree of aggregation in $\mathrm{Cu} 100$ nanoparticle suspensions than they do in $\mathrm{Cu} 50$ nanoparticle suspensions. In aqueous $\mathrm{Cu} 100$ suspensions when concentration increases from 0.1 to $1 \mathrm{mg} / \mathrm{L} d_{\mathrm{av}}$ of the aggregates becomes 1.5-2 times smaller regardless of the storage time (Figures 6(a) and 


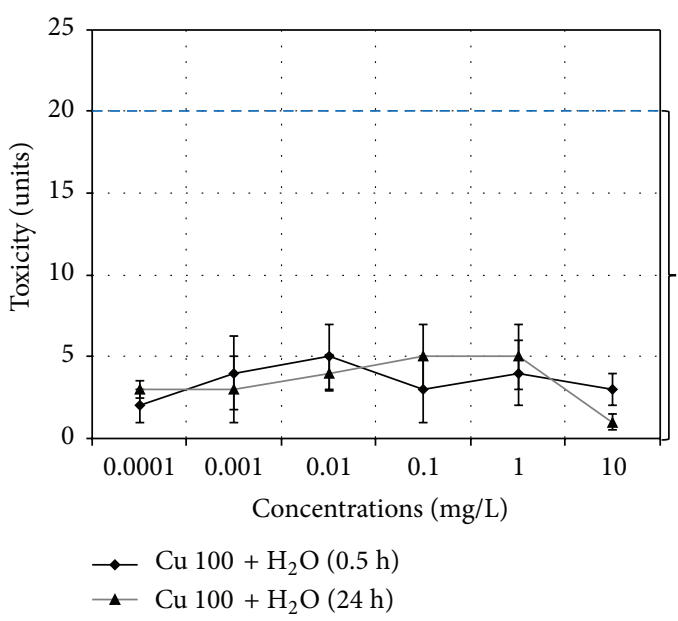

(a)

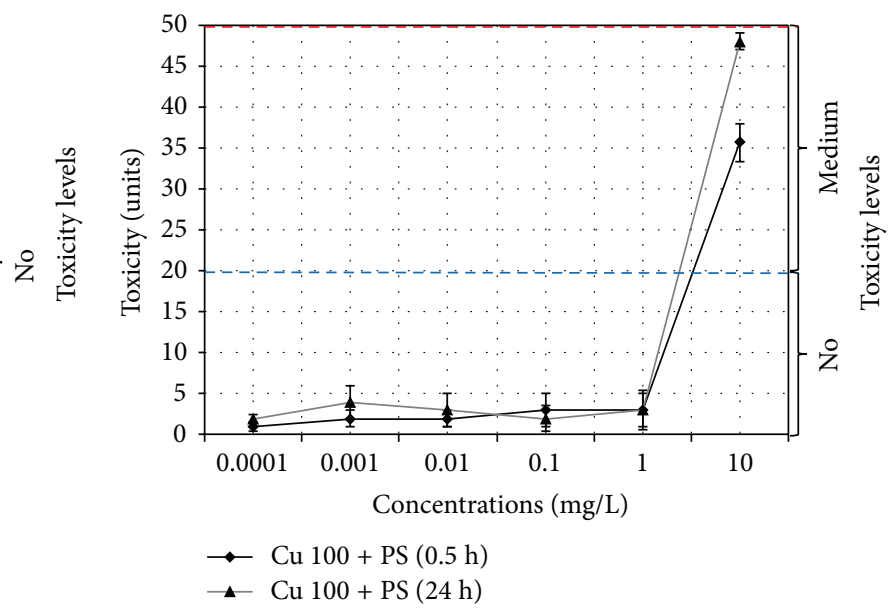

(b)

Figure 5: Changes in the toxicity index for $\mathrm{Cu} 100$ nanoparticle suspensions based on (a) water, $\mathrm{Cu} 100+\mathrm{H}_{2} \mathrm{O}$, and (b) physiological solution, $\mathrm{Cu} 100+$ PS.

TABLE 3: $\mathrm{pH}$ value of the studied $\mathrm{Cu} 100$ nanoparticle suspensions.

\begin{tabular}{lcccc}
\hline Concentrations $(\mathrm{mg} / \mathrm{L})$ & $\mathrm{Cu} 100+\mathrm{H}_{2} \mathrm{O}(0.5 \mathrm{~h})$ & $\mathrm{Cu} 100+\mathrm{H}_{2} \mathrm{O}(24 \mathrm{~h})$ & $\mathrm{Cu} 100+\mathrm{PS}(0.5 \mathrm{~h})$ & $\mathrm{Cu} 100+\mathrm{PS}(24 \mathrm{~h})$ \\
\hline 0.0001 & 7.0 & 7.1 & 7.0 & 7.1 \\
0.001 & 7.2 & 7.1 & 7.1 & 7.4 \\
0.01 & 7.3 & 7.2 & 7.1 & 7.5 \\
0.1 & 7.3 & 7.2 & 7.1 & 7.4 \\
1 & 7.3 & 7.2 & 7.7 & 7.4 \\
10 & 7.2 & 7.4 & 7.2 \\
\hline
\end{tabular}

6(b)). In concentrated suspensions with $10 \mathrm{mg} / \mathrm{L} d_{\mathrm{av}}$ of the aggregates rises sharply while their storage for more than 24 hours has little effect on $d_{\mathrm{av}}$ which can be explained by the particles settling (Figure 6(a)). In PS suspensions $d_{\mathrm{av}}$ of the aggregates gradually increases together with particles concentration growth. Increase in storage time for PS suspensions resulted in no significant aggregation (Figure 6(b)).

Comparison of the toxic properties of nanoparticles of various sizes shows that decrease in nanoparticle size from 100 to $50 \mathrm{~nm}$ leads to sharp rise of toxicity index; this effect is especially characteristic for diluted suspension with copper concentration $<0.01 \mathrm{mg} / \mathrm{L}$. Since aggregate size has almost now influence on biological activity variation it may be concluded that particle size decrease leads to toxicity growth because of increasing number of surface atoms which have higher activity due to unsaturated bonds. Thus, for example, nanoparticles are characterized by high surface atoms to volume ratio. This fact may be of great significance for the whole spectrum of the properties displayed by a substance including its chemical, physicochemical, and biological activity [57].

At the same time, the team obtained evidence that in 24 hours activity of $\mathrm{Cu} 50$ nanoparticles decreased in comparison with that of $\mathrm{Cu} 100$ nanoparticles. Since the size of the particles/aggregates does not change much (Figures 4 and 6), such difference in behavior can be explained by peculiarities of chemical composition of the surface layers of the particles composing the aggregates in water suspensions. In the work quoted previously [55] it was shown by the example of similar objects of study (electroexplosive cuprum nanoparticles) that during the first hours of exposition in water the specific rate of metallic ions release from $\mathrm{Cu} 50$ nanoparticles is much lower than that from $\mathrm{Cu} 100$ nanoparticles. The mechanism suggested by the authors implies that low-solubility oxidehydroxide cuprum compounds, inseparable by centrifugation, are formed on the surface with time, while the dissolution rate differs by $1-2 \% \mathrm{wt}$. Thus, we can suggest that in spite of formation of a hard phase new composition on the surface of particles there still remains high content of highly toxic $\mathrm{Cu}^{2+}$ ions in $\mathrm{Cu} 100$ suspension; these ions are responsible for high toxicity of larger particles after $24 \mathrm{~h}$ exposure.

3.3. Study of $\mathrm{Cu}^{2+}$ Ions Solutions Toxicity. It is deduced from experiments that $\mathrm{Cu}^{2+}$ solutions with concentration $\leq 1 \mathrm{mg} / \mathrm{L}$ display no cytotoxicity (Figures 7(a) and 7(b)). High toxicity level (>90 units) is observed at $10 \mathrm{mg} / \mathrm{L}$ concentration, while storage time influence upon bactericidal effect is noted only for PS-based solutions: toxic effect disappears after 24-hour storage. Minimum inhibitory concentration (MIC) for water solutions and for fresh suspension based on physical solution is $2 \mathrm{mg} / \mathrm{L}$. Minimum bactericidal concentration (MBC) for water solutions is $10 \mathrm{mg} / \mathrm{L}$; for fresh suspension based on physical solution it is $10 \mathrm{mg} / \mathrm{L}$. For 24-hour suspension based on physical solution neither MIC nor MBC were calculated. 


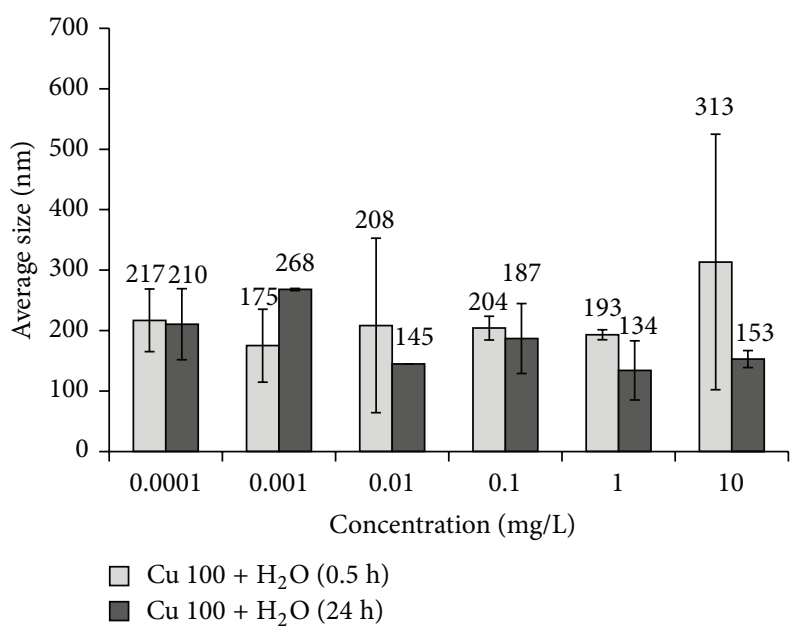

(a)

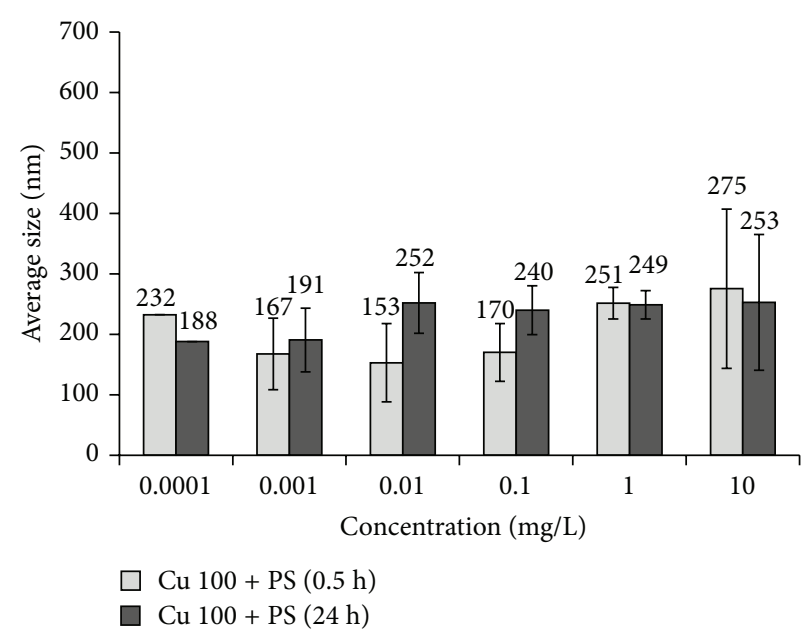

(b)

Figure 6: Changes in average size of $\mathrm{Cu} 100$ nanoparticle suspensions based on (a) water, $\mathrm{Cu} 100+\mathrm{H}_{2} \mathrm{O}$, and (b) physiological solution, $\mathrm{Cu}$ $100+$ PS.

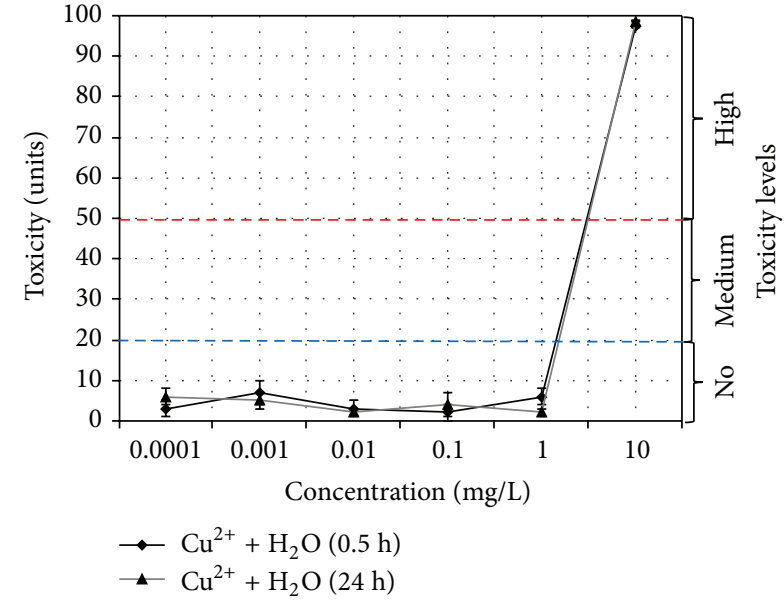

(a)

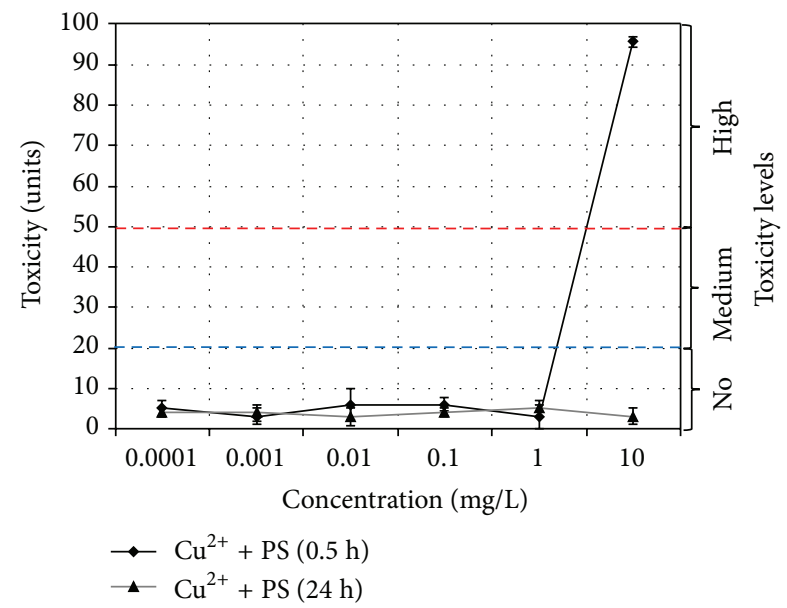

(b)

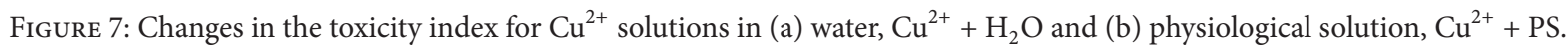

Change in $\mathrm{pH}$ level of the solutions has no influence on their toxicity value as the highest deviation from the norm produces no biocidal effect (Table 4).

One can reasonably suggest that on the one hand high toxicity of $\mathrm{Cu}^{2+}$ solutions at $10 \mathrm{mg} / \mathrm{L}$ concentration can be connected with reaching some threshold concentration of $\mathrm{Cu}^{2+}$ ions when high concentration gradient leads to increasing amount of ions diffusing into the cell through cytoplasmic membrane. On the other hand, aqueous $\mathrm{Cu}^{2+}$ solutions in neutral and weak basic media are characterized by some degree of instability. According to $\mathrm{pH}$ measurements $\mathrm{pH}$ values decreased from 7.2 to $6.3 \cdots 6.6$ units (Table 4 ), which had to increase the hydrolytic stability of the solutions. With increase in the solution concentration up to $10 \mathrm{mg} / \mathrm{L}$ the concentrations product $\mathrm{Cu}(\mathrm{OH})_{2}$ will exceed the dissociation constant; consequently the deposited amorphous particles of copper hydroxides can adhere to the cell surface leading to membrane permeability deterioration thus disrupting the cell life functions.

3.4. Control Toxicity check In Bactericidal Solution of SDC. The control study of the influence of widely employed antibacterial agent shows that toxicity index has negative or zero values at substance concentration $<1 \mathrm{mg} / \mathrm{L}$. It can be decisively stated that only at concentrations exceeding this value almost complete biosensor luminescence quenching is observed in all the studied media while storage time has no notable effect on the product antimicrobial properties (Figures $8(\mathrm{a})$ and $8(\mathrm{~b})$ ) and on initial $\mathrm{pH}$ value of 7.2.

Minimum inhibitory concentration (MIC) for fresh water solution is $0.25 \mathrm{mg} / \mathrm{L}$, and for 24 -hour suspension it is $2 \mathrm{mg} / \mathrm{L}$. For suspensions based on physical solution it is $2 \mathrm{mg} / \mathrm{L}$. Minimum bactericidal concentrations (MBC) for freshly prepared and 24-hours water solutions and for fresh suspension based 
TABLE 4: $\mathrm{pH}$ levels of $\mathrm{Cu}^{2+}$ solutions.

\begin{tabular}{lcccc}
\hline Concentrations $(\mathrm{mg} / \mathrm{L})$ & $\mathrm{Cu}^{2+}+\mathrm{H}_{2} \mathrm{O}(0.5 \mathrm{~h})$ & $\mathrm{Cu}^{2+}+\mathrm{H}_{2} \mathrm{O}(24 \mathrm{~h})$ & $\mathrm{Cu}^{2+}+\mathrm{PS}(0.5 \mathrm{~h})$ & 7.1 \\
$\mathrm{Cu}$ & 7.2 & 7.2 & 7.2 \\
0.0001 & 7.2 & 7.3 & 7.1 & 7.2 \\
0.001 & 7.2 & 7.3 & 7.1 & 7.3 \\
0.1 & 7.2 & 7.2 & 7.0 & 7.2 \\
1 & 7.2 & 7.1 & 6.6 & 7.1 \\
10 & 7.1 & 7.1 & & 6.3 \\
\hline
\end{tabular}

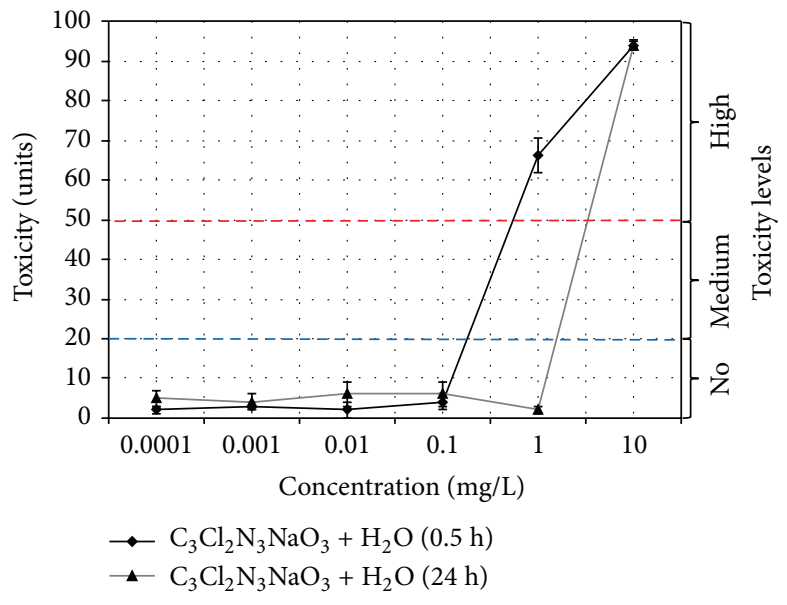

(a)

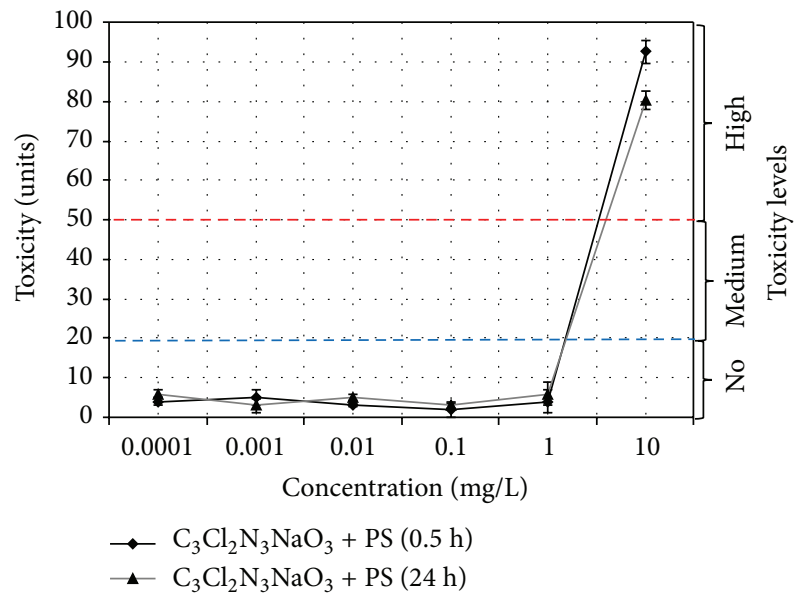

(b)

FIGURE 8: Changes in the toxicity index for SDC solutions $\left(\mathrm{C}_{3} \mathrm{Cl}_{2} \mathrm{~N}_{3} \mathrm{NaO}_{3}\right)$ in (a) water and (b) physiological solution (PS).

on physical solution was $10 \mathrm{mg} / \mathrm{L}$. MBC was not evaluated for 24-hour suspension based on physical solution within the studied range of concentrations.

\section{Conclusion}

Thus, the present work displays the influence of such factors as storage time, composition, and concentration of coppercontaining solutions and suspensions upon their bactericidal effect against E. coli M-17 bacteria.

Comparative analysis of the influence of various characteristics of $\mathrm{Cu} 50$ and $\mathrm{Cu} 100$ nanoparticle suspensions upon their performance against $E$. coli enabled us to determine the most efficient concentrations $(\mathrm{mg} / \mathrm{L})$ displaying the highest antibacterial effect (Table 5).

It was determined that reduction of nanoparticles initial size from 100 to $50 \mathrm{~nm}$ results in rise in their antimicrobial activity; at the same time character of the dependence of toxicity on concentration also changes as toxicity peaks at low concentrations $(0.0001 \cdots 0.01 \mathrm{mg} / \mathrm{L})$ are observed. The obtained results correspond with the available data on increased toxicity of nanoparticles of smaller size [58-60] and on nonlinear character of nanotoxicity, which may result from such factors as step-like character of adaptation of living organisms to stresses, signaling role of low-intensity nanoparticle influence, nonlinear stochastic resonance induced by weak influences $[61,62]$.

Furthermore, no influence of medium-sized nanoparticles/aggregates in suspensions upon their antibacterial properties was noted. It was shown that the suspensions storage time is an important factor altering antimicrobial properties of small nanoparticle suspensions of $\mathrm{Cu} 50$ where toxicity decreases after 24-hour storage, while suspensions of larger $\mathrm{Cu} 100$ nanoparticles display no such dependence.

It was found that dispersion medium has different influence on antibacterial properties of suspensions containing nanoparticles of different sizes: unlike $\mathrm{Cu} 50$, highconcentration suspensions of $\mathrm{Cu} 100$ nanoparticles $(10 \mathrm{mg} / \mathrm{L})$ display higher toxicity when physiological solution is used instead of water.

The conducted experiments enabled us to detect differences in toxicological effects of nanostructured and ionic forms of copper. In large, $\mathrm{Cu}^{2+}$ solutions display lower level of toxicity at concentrations of $0.0001 \cdots 1 \mathrm{mg} / \mathrm{L}$ than $\mathrm{Cu} 50$ nanoparticle suspensions. Although at the maximum concentration of $10 \mathrm{mg} / \mathrm{L}$ copper in ionic form shows the highest toxic effect comparable with that of antimicrobial product based on aqueous solution of $\mathrm{C}_{3} \mathrm{Cl}_{2} \mathrm{~N}_{3} \mathrm{NaO}_{3}$. 
TABle 5: The most efficient concentrations ( $\mathrm{mg} / \mathrm{L})$ displaying the maximum antibacterial effect.

\begin{tabular}{lcccc}
\hline Conditions: media and storage time & $\begin{array}{c}\text { Nanoparticle suspension } \\
\mathrm{Cu} \mathrm{50}\end{array}$ & $\begin{array}{c}\text { Nanoparticle suspension } \\
\mathrm{Cu} 100\end{array}$ & $\mathrm{Cu}^{2+}$ solution & $\mathrm{C}_{3} \mathrm{Cl}_{2} \mathrm{~N}_{3} \mathrm{NaO}_{3}$ solution \\
\hline $\mathrm{H}_{2} \mathrm{O}$ 0.5 $\mathrm{h}$ & $0.0001 ; 10^{*}$ & - & 10 & $1 ; 10$ \\
$\mathrm{H}_{2} \mathrm{O} 24 \mathrm{~h}$ & - & - & 10 & 10 \\
PS 0.5 h & $0.01 ; 10^{*}$ & 10 & 10 & 10 \\
PS 24 h & - & 10 & - & 10 \\
\hline
\end{tabular}

${ }^{*}$ Nonlinear toxicity effects.

The received results can be used for creating new types of antibacterial products based on nanoscale copper particles as well as for development of methods for toxicity forecasting and evaluation of aqueous solutions containing copper.

\section{Conflict of Interests}

The authors declare that there is no conflict of interests regarding the publication of this paper.

\section{Acknowledgments}

The authors gratefully acknowledge the financial support of the Ministry of Education and Science of the Russian Federation (Project no. RFMEFI57814X0080) and from the framework of Increase Competitiveness Program of NUST "MISiS" (in part of analysis of the properties of colloidal suspensions).

\section{References}

[1] C. B. Murray, C. R. Kagan, and M. G. Bawendi, "Synthesis and characterization of monodisperse nanocrystals and closepacked nanocrystal assemblies," Annual Review of Materials Science, vol. 30, pp. 545-610, 2000.

[2] O. V. Salata, "Applications of nanoparticles in biology and medicine," Journal of Nanobiotechnology, vol. 2, article 3, 2004.

[3] M. C. Roco, C. A. Mirkin, and M. C. Hersam, "Nanotechnology research directions for societal needs in 2020: summary of international study," Journal of Nanoparticle Research, vol. 13, no. 3, pp. 897-919, 2011.

[4] M. Fakruddin, Z. Hossain, and H. Afroz, "Prospects and applications of nanobiotechnology: a medical perspective," Journal of Nanobiotechnology, vol. 10, article 31, 2012.

[5] A. Azam, A. S. Ahmed, M. Oves, M. S. Khan, S. S. Habib, and A. Memic, "Antimicrobial activity of metal oxide nanoparticles against Gram-positive and Gram-negative bacteria: a comparative study," International Journal of Nanomedicine, vol. 7, pp. 6003-6009, 2012.

[6] W. Liu, P. Su, S. Chen et al., "Synthesis of $\mathrm{TiO}_{2}$ nanotubes with $\mathrm{ZnO}$ nanoparticles to achieve antibacterial properties and stem cell compatibility," Nanoscale, vol. 6, no. 15, pp. 9050-9062, 2014.

[7] A. Besinis, T. de Peralta, and R. D. Handy, "The antibacterial effects of silver, titanium dioxide and silica dioxide nanoparticles compared to the dental disinfectant chlorhexidine on Streptococcus mutans using a suite of bioassays," Nanotoxicology, vol. 8, no. 1, pp. 1-16, 2014.
[8] Antibiotic Resistance Major Public Health Problem [Digital resource], http://www.medicalnewstoday.com/articles/252956 .php.

[9] Alliance for the Prudent Use of Antibiotics (APUA), What is Antibiotic Resistance and Why is it a problem? [Digital resource], http://www.tufts.edu/med/apua/about_issue/antibiotic_res.shtml.

[10] WHO, "Atibiotic resistance reveals serious, worldwide threat to public health [Digital resource]," WHO Report, World Health Organization, Media Centre, 2014, http://www.who.int/mediacentre/news/releases/2014/amr-report/ru/.

[11] M. J. Hajipour, K. M. Fromm, A. Akbar Ashkarran et al., "Antibacterial properties of nanoparticles," Trends in Biotechnology, vol. 30, no. 10, pp. 499-511, 2012.

[12] Z. Huang, X. Zheng, D. Yan et al., "Toxicological effect of $\mathrm{ZnO}$ nanoparticles based on bacteria," Langmuir, vol. 24, no. 8, pp. 4140-4144, 2008.

[13] D. Roe, B. Karandikar, N. Bonn-Savage, B. Gibbins, and J.B. Roullet, "Antimicrobial surface functionalization of plastic catheters by silver nanoparticles," Journal of Antimicrobial Chemotherapy, vol. 61, no. 4, pp. 869-876, 2008.

[14] S. S. Khan, A. Mukherjee, and N. Chandrasekaran, "Studies on interaction of colloidal silver nanoparticles (SNPs) with five different bacterial species," Colloids and Surfaces B: Biointerfaces, vol. 87, no. 1, pp. 129-138, 2011.

[15] M. Ahamed, H. A. Alhadlaq, M. A. Khan, P. Karuppiah, and N. A. Al-Dhabi, "Synthesis, characterization, and antimicrobial activity of copper oxide nanoparticles," Journal of Nanomaterials, vol. 2014, Article ID 637858, 4 pages, 2014.

[16] R. Yoshida, D. Kitamura, and S. Maenosono, "Mutagenicity of water-soluble $\mathrm{ZnO}$ nanoparticles in Ames test," The Journal of Toxicological Sciences, vol. 34, no. 1, pp. 119-122, 2009.

[17] S. Maenosono, T. Suzuki, and S. Saita, "Mutagenicity of watersoluble FePt nanoparticles in Ames test," The Journal of Toxicological Sciences, vol. 32, no. 5, pp. 575-579, 2007.

[18] W. Jiang, H. Mashayekhi, and B. Xing, "Bacterial toxicity comparison between nano- and micro-scaled oxide particles," Environmental Pollution, vol. 157, no. 5, pp. 1619-1625, 2009.

[19] J. S. Kim, E. Kuk, K. N. Yu et al., "Antimicrobial effects of silver nanoparticles," Nanomedicine: Nanotechnology, Biology, and Medicine, vol. 3, no. 1, pp. 95-101, 2007.

[20] K. Giannousi, K. Lafazanis, J. Arvanitidis, A. Pantazaki, and C. Dendrinou-Samara, "Hydrothermal synthesis of copper based nanoparticles: antimicrobial screening and interaction with DNA," Journal of Inorganic Biochemistry, vol. 133, pp. 24-32, 2014.

[21] M. Veerapandian, S. Sadhasivam, J. Choi, and K. Yun, "Glucosamine functionalized copper nanoparticles: preparation, characterization and enhancement of anti-bacterial activity by 
ultraviolet irradiation," Chemical Engineering Journal, vol. 209, pp. 558-567, 2012.

[22] A. A. Rakhmetova, Study of biological activity of copper nanoparticles with differing dispersion and phase composition, author's abstract for Cand. Sc. (Biology), Moscow, Russia, 2011.

[23] I. V. Babushkina, I. A. Mamontova, and E. V. Gladkova, "Metal nanoparticles reduce bacterial contamination of experimental purulent wounds," Bulletin of Experimental Biology and Medicine, vol. 158, no. 5, pp. 692-694, 2015.

[24] A. K. Chatterjee, R. Chakraborty, and T. Basu, "Mechanism of antibacterial activity of copper nanoparticles," Nanotechnology, vol. 25, no. 13, Article ID 135101, 2014.

[25] J. Díaz-Visurraga, C. Daza, C. Pozo, A. Becerra, C. von Plessing, and A. García, "Study on antibacterial alginate-stabilized copper nanoparticles by FT-IR and 2D-IR correlation spectroscopy," International Journal of Nanomedicine, vol. 7, pp. 3597-3612, 2012.

[26] R. Sivaraj, P. K. Rahman, P. Rajiv, H. A. Salam, and R. Venckatesh, "Biogenic copper oxide nanoparticles synthesis using Tabernaemontana divaricate leaf extract and its antibacterial activity against urinary tract pathogen," Spectrochimica Acta Part A: Molecular and Biomolecular Spectroscopy, vol. 133, pp. 178-181, 2014.

[27] M. Agarwala, B. Choudhury, and R. N. S. Yadav, "Comparative study of antibiofilm activity of copper oxide and iron oxide nanoparticles against multidrug resistant biofilm forming uropathogens," Indian Journal of Microbiology, vol. 54, no. 3, pp. 365-368, 2014.

[28] P. Swain, S. K. Nayak, A. Sasmal et al., "Antimicrobial activity of metal based nanoparticles against microbes associated with diseases in aquaculture," World Journal of Microbiology and Biotechnology, vol. 30, no. 9, pp. 2491-2502, 2014.

[29] V. V. T. Padil and M. Černík, "Green synthesis of copper oxide nanoparticles using gum karaya as a biotemplate and their antibacterial application," International Journal of Nanomedicine, vol. 8, pp. 889-898, 2013.

[30] A. Pramanik, D. Laha, D. Bhattacharya, P. Pramanik, and P. Karmakar, "A novel study of antibacterial activity of copper iodide nanoparticle mediated by DNA and membrane damage," Colloids and Surfaces B: Biointerfaces, vol. 96, pp. 50-55, 2012.

[31] P. Mantecca, E. Moschini, P. Bonfanti et al., "Toxicity evaluation of a New $\mathrm{Zn}$-Doped $\mathrm{CuO}$ nanocomposite with highly effective antibacterial properties," Toxicological Sciences, 2015.

[32] A. L. D. O. F. Rossetto, D. S. Vicentini, C. H. Costa, S. P. Melegari, and W. G. Matias, "Synthesis, characterization and toxicological evaluation of a core-shell copper oxide/polyaniline nanocomposite," Chemosphere, vol. 108, pp. 107-114, 2014.

[33] L. A. Tamayo, P. A. Zapata, F. M. Rabagliati et al., "Antibacterial and non-cytotoxic effect of nanocomposites based in polyethylene and copper nanoparticles," Journal of Materials Science: Materials in Medicine, vol. 26, no. 3, article 129, 2015.

[34] S. Shankar, X. Teng, and J. Rhim, "Properties and characterization of agar/CuNP bionanocomposite films prepared with different copper salts and reducing agents," Carbohydrate Polymers, vol. 114, pp. 484-492, 2014.

[35] C. Gunawan, W. Y. Teoh, C. P. Marquis, and R. Amal, "Cytotoxic origin of copper (II) oxide nanoparticles: comparative studies with micron-sized particles, leachate, and metal salts," ACS Nano, vol. 5, no. 9, pp. 7214-7225, 2011.

[36] K. Midander, I. O. Wallinder, and C. Leygraf, "In vitro studies of copper release from powder particles in synthetic biological media," Environmental Pollution, vol. 145, no. 1, pp. 51-59, 2007.
[37] J. J. Hostynek and H. I. Maibach, "Copper hypersensitivity: dermatologic aspects-an overview," Reviews on Environmental Health, vol. 18, no. 3, pp. 153-183, 2003.

[38] G. Borrow and J. Gabbay, "Putting copper into action: copperimpregnated products with potent biocidal activities," The FASEB Journal, vol. 18, no. 14, pp. 1728-1730, 2004.

[39] S. S. Timofeyev, "Water oxidation of $\mathrm{Al} / \mathrm{AlN} / \mathrm{Cu}$ and $\mathrm{Al} / \mathrm{AlN} / \mathrm{Zn}$ nanopowders for creating microbiologically active sorbents," in Proceedings of the 10th International Conference of Students and Young Scientists "Prospects of Fundamental Sciences Development", National Research Tomsk Polytechnic University, Tomsk, Russia, April 2013, http://science-persp.tpu.ru/ Previous\%20Materials/Konf_2013.pdf.

[40] N. S. Heliopoulos, S. K. Papageorgiou, A. Galeou, E. P. Favvas, F. K. Katsaros, and K. Stamatakis, "Effect of copper and copper alginate treatment on wool fabric. Study of textile and antibacterial properties," Surface \& Coatings Technology, vol. 235, pp. 24-31, 2013.

[41] N. A. Amro, L. P. Kotra, K. Wadu-Mesthrige, A. Bulychev, S. Mobashery, and G.-Y. Liu, "High-resolution atomic force microscopy studies of the Escherichia coli outer membrane: structural basis for permeability," Langmuir, vol. 16, no. 6, pp. 2789-2796, 2000.

[42] K. Kon and M. Rai, "Metallic nanoparticles: mechanism of antibacterial action and influencing factors," Journal of Comparative Clinical Pathology Research, vol. 2, no. 1, pp. 160-174, 2013.

[43] S. Pal, Y. K. Tak, and J. M. Song, "Does the antibacterial activity of silver nanoparticles depend on the shape of the nanoparticle? A study of the gram-negative bacterium Escherichia coli," Applied and Environmental Microbiology, vol. 73, no. 6, pp. 17121720, 2007.

[44] T. Theivasanthi and M. Alagar, "Studies of copper nanoparticles effects on micro organisms," Annals of Biological Research, vol. 2, no. 3, pp. 368-373, 2011, http://scholarsresearchlibrary.com/ archive.html.

[45] I. Subhankari and P. L. Nayak, "Antimicrobial activity of copper nanoparticles synthesised by ginger (Zingiber officinale) extract," World Journal of Nano Science \& Technology, vol. 2, no. 1, pp. 10-13, 2013.

[46] M. S. Usman, M. E. El Zowalaty, K. Shameli, N. Zainuddin, M. Salama, and N. A. Ibrahim, "Synthesis, characterization, and antimicrobial properties of copper nanoparticles," International Journal of Nanomedicine, vol. 8, no. 1, pp. 4467-4479, 2013.

[47] E. I. Alarcon, K. Udekwu, M. Skog et al., “The biocompatibility and antibacterial properties of collagen-stabilized, photochemically prepared silver nanoparticles," Biomaterials, vol. 33, no. 19, pp. 4947-4956, 2012.

[48] M. R. Shah, S. Ali, M. Ateeq et al., "Morphological analysis of the antimicrobial action of silver and gold nanoparticles stabilized with ceftriaxone on Escherichia coli using atomic force microscopy," New Journal of Chemistry, vol. 38, no. 11, pp. 56335640, 2014.

[49] Metal nanopowders [digital resource], http://www.nanosizedpowders.com/.

[50] Disinfectant Nika-Chlor [digital resource], http://geniks.ru/ catalog/medical/hlors/.

[51] I. Lopes, R. Ribeiro, F. E. Antunes et al., "Toxicity and genotoxicity of organic and inorganic nanoparticles to the bacteria Vibrio fischeri and Salmonella typhimurium," Ecotoxicology, vol. 21, no. 3, pp. 637-648, 2012.

[52] A. Garcia, S. Recillas, A. Sánchez, and X. Font, “The luminescent bacteria test to determine the acute toxicity of nanoparticle 
suspensions," Methods in Molecular Biology, vol. 926, pp. 255259, 2012.

[53] O. A. Mogil'naia, A. P. Puzyr', and V. S. Bondar', "Growth and bioluminescence of luminous bacteria under the action of aflatoxin B1 before and after its treatment with nanodiamonds," Prikladnaia Biokhimiia i Mikrobiologiia, vol. 46, no. 1, pp. 4044, 2010.

[54] A. P. Zarubina, E. P. Lukashev, L. I. Deev, I. M. Parkhomenko, and A. B. Rubin, "Biotesting the biological effects of single-wall carbon nanotubes using bioluminescent bacteria test-system," Nanotechnologies in Russia, vol. 4, no. 11-12, pp. 871-875, 2009.

[55] A. Y. Godymchuk, G. G. Savel'ev, and D. V. Gorbatenko, "Dissolution of copper nanopowders in inorganic biological media," Russian Journal of General Chemistry, vol. 80, no. 5, pp. 881-888, 2010.

[56] D. J. Finney, Probit Analysis, Cambridge University Press, Cambridge, UK, 3rd edition, 1971.

[57] L. C. Renwick, D. Brown, A. Clouter, and K. Donaldson, "Increased inflammation and altered macrophage chemotactic responses caused by two ultrafine particle types," Occupational and Environmental Medicine, vol. 61, no. 5, pp. 442-447, 2004.

[58] S. Nair, A. Sasidharan, V. V. D. Rani, D. Menon, K. Manzoor, and S. Raina, "Role of size scale of $\mathrm{ZnO}$ nanoparticles and microparticles on toxicity toward bacteria and osteoblast cancer cells," Journal of Materials Science: Materials in Medicine, vol. 20, no. 1, pp. S235-S241, 2009.

[59] G. A. Martinez-Castanon, N. Niño-Martínez, F. MartínezGutierrez, J. R. Martínez-Mendoza, and F. Ruiz, "Synthesis and antibacterial activity of silver nanoparticles with different sizes," Journal of Nanoparticle Research, vol. 10, no. 8, pp. 1343-1348, 2008.

[60] H. L. Karlsson, J. Gustafsson, P. Cronholm, and L. Möller, "Sizedependent toxicity of metal oxide particles-a comparison between nano- and micrometer size," Toxicology Letters, vol. 188, no. 2, pp. 112-118, 2009.

[61] I. R. Bell, J. A. Ives, and W. B. Jonas, "Nonlinear effects of nanoparticles: biological variability from hormetic doses, small particle sizes, and dynamic adaptive interactions," DoseResponse, vol. 12, no. 2, pp. 202-232, 2014.

[62] S. V. Stovbun, A. V. Kiselev, A. M. Zanin et al., "Effects of physicochemical forms of phenazepam and panavir on their action at ultra-low doses," Bulletin of Experimental Biology and Medicine, vol. 153, no. 4, pp. 455-458, 2012. 

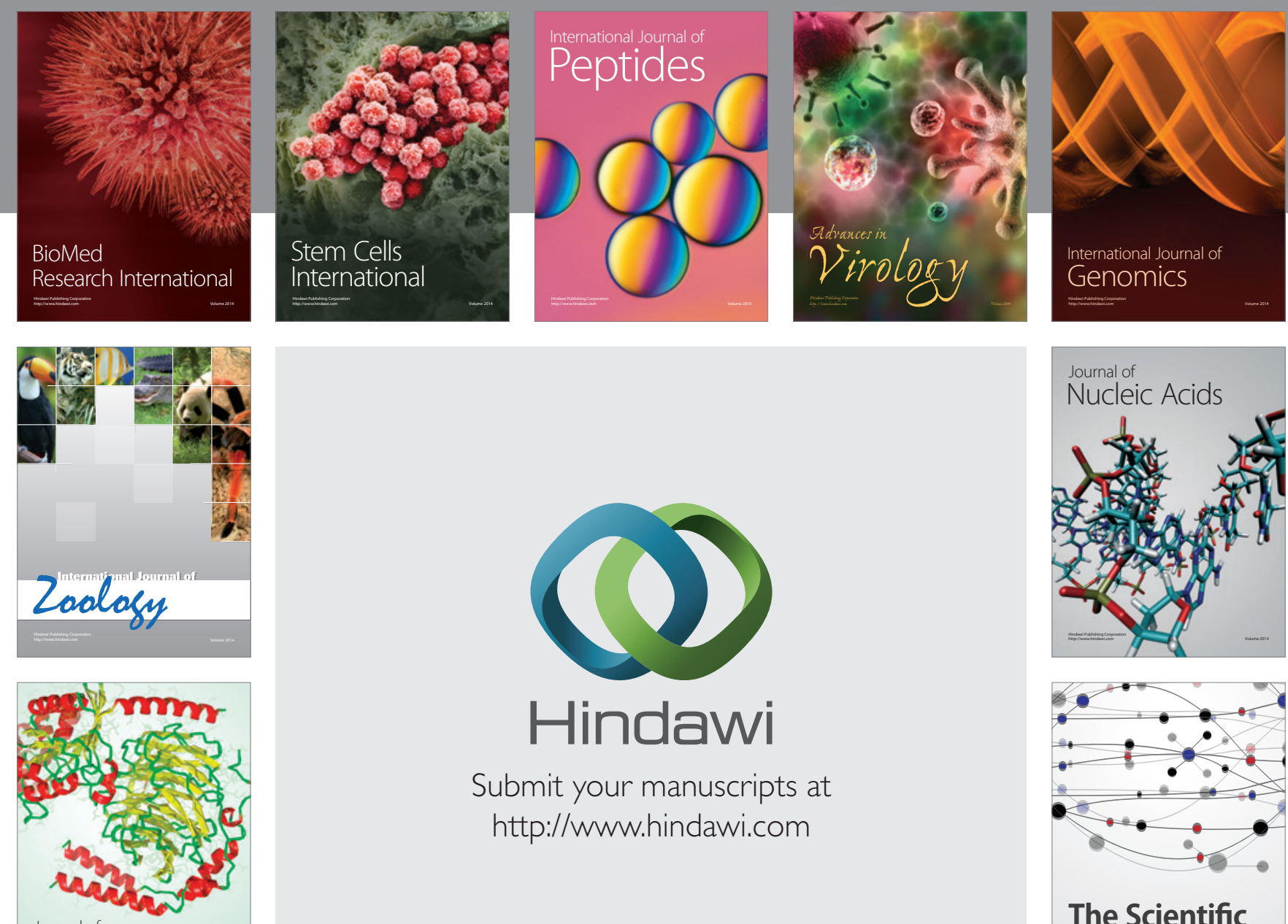

Submit your manuscripts at

http://www.hindawi.com

Journal of
Signal Transduction
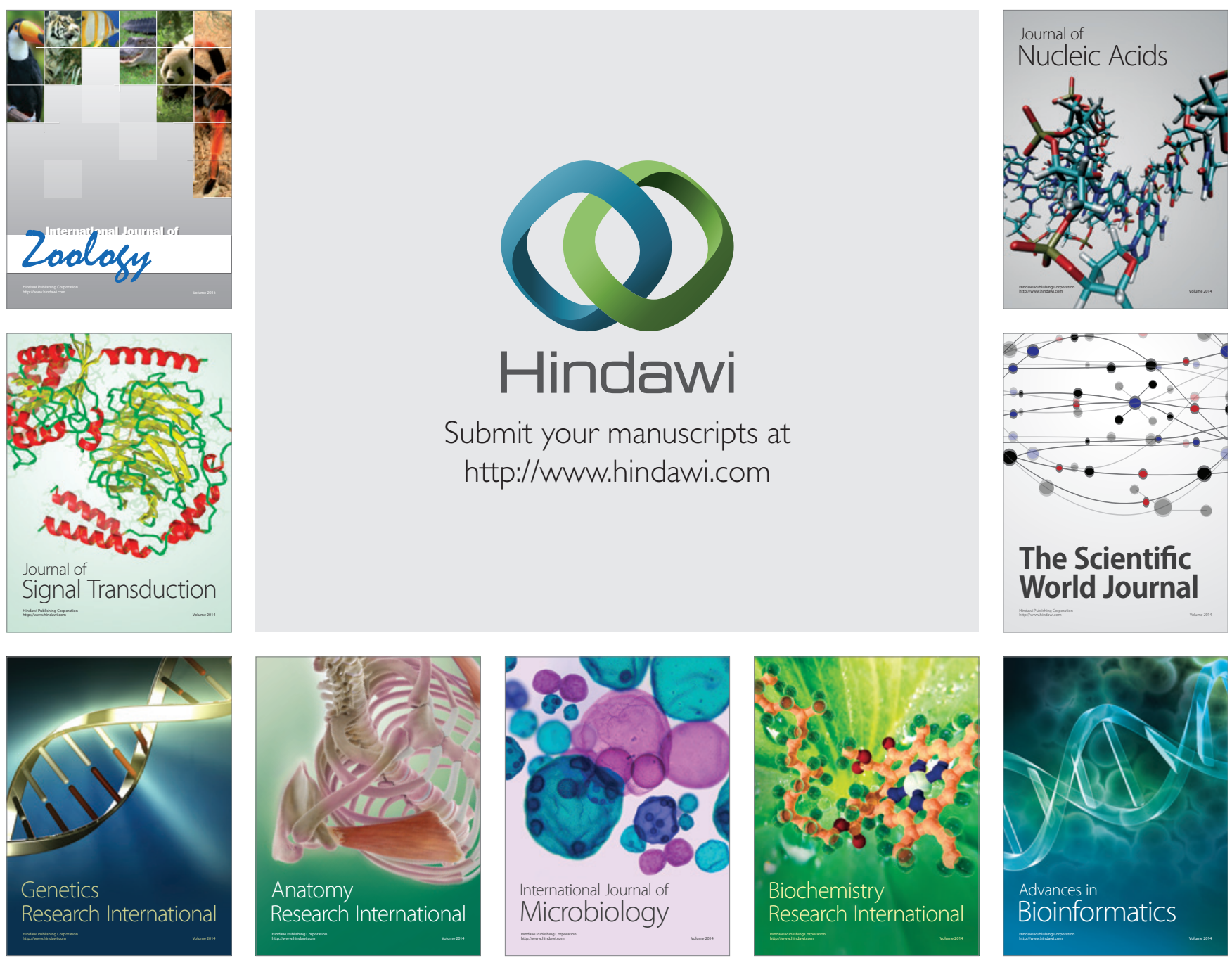

The Scientific World Journal
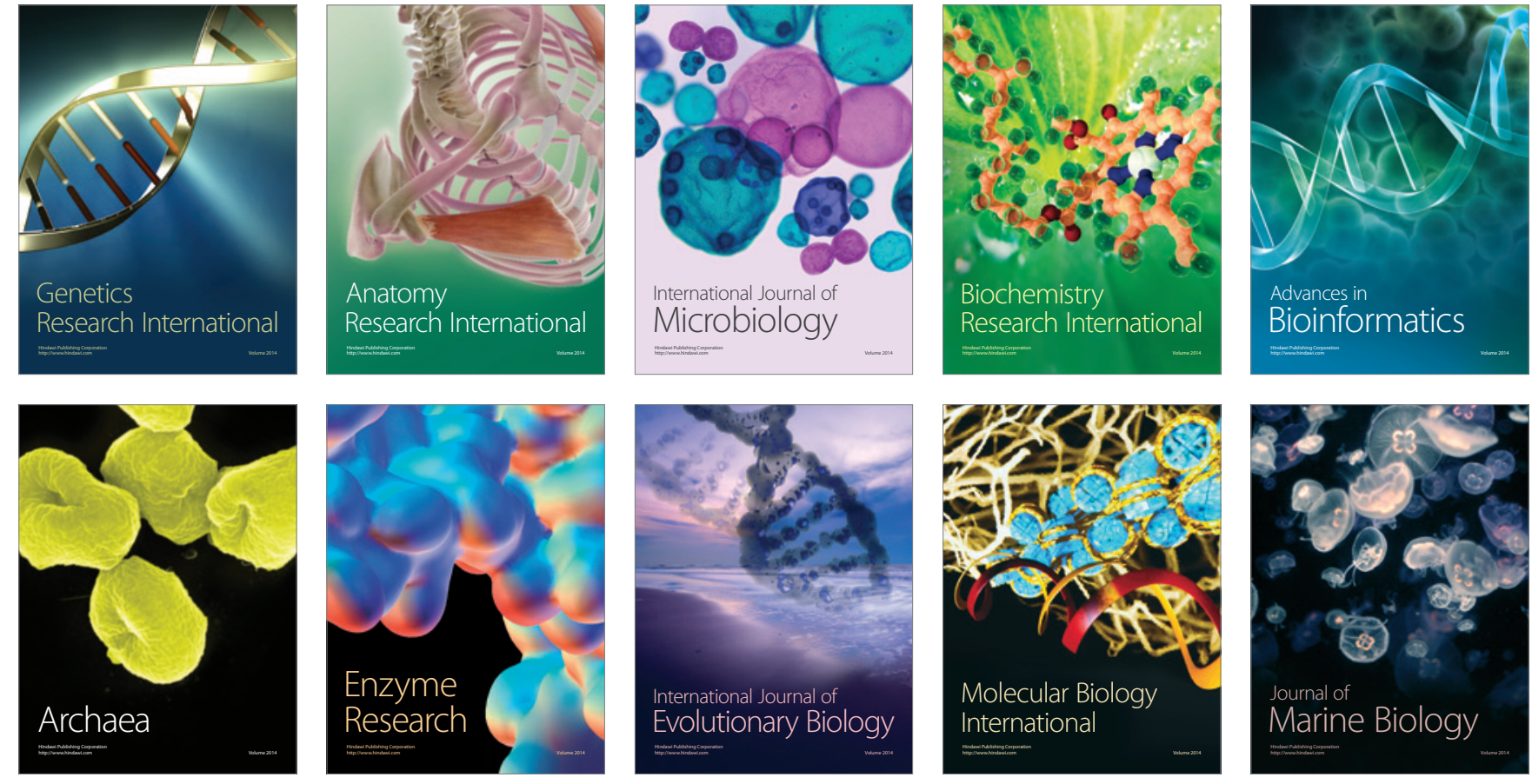